J. Indones. Math. Soc. (MIHMI)

Vol. 14, No. 1 (2008), pp. 25-35.

\title{
EXTENDED LUCAS TUBE: GRAF HAMILTONIAN BARU
}

\author{
Ernastuti, Djati Kerami, Belawati H Widjaya
}

\begin{abstract}
A Hamiltonian cycle in a connected graph $G$ is defined as a closed walk that traverses every vertex of $G$ exactly once, except the starting vertex at which the walk also terminates. If an edge from a Hamiltonian cycle is removed, it forms a path called a Hamiltonian path. A graph $G$ is called Hamiltonian if there is a Hamiltonian cycle in $G$. It is known that every hypercube graph is Hamiltonian. But when one or more vertices are removed from a hypercube graph, will it still be Hamiltonian? Some induced subgraphs of a hypercube graph such as the Fibonacci cube (FC), the extended Fibonacci cube (EFC), and the Lucas cube (LC) have been introduced and their Hamiltonicities have been investigated. Research results showed that less than a third of FC graphs are Hamiltonian although all of them have Hamiltonian path. All EFC graphs are Hamiltonian and none of LC graphs is Hamiltonian although some still have Hamiltonian paths. This paper introduces another subgraph of a hypercube graph called the Extended Lucas Cube (ELC). The ELC is shown to be Hamiltonian by using the approach of k-Gray Code and Bipartition Property.
\end{abstract}

Received 25-01-2008, Accepted 13-11-2008.

2000 Mathematics Subject Classification: 05C45

Key words and Phrases: String biner, hypercube, extended Fibonacci cube, jarak Hamming, k-kode gray, Hamiltonian, sikul Hamiltonian, bipartisi

Ernastuti: Fakultas Teknologi Informasi dan Ilmu Komputer, Universitas Gunadarma, Depok, Indonesia.

E-mail: ernas@staff.gunadarma.ac.id

Djati Kerami: Fakultas Matematika dan Ilmu Pasti Alam, Universitas Indonesia, Depok, Indonesia. E-mail: djatikr@ui.edu

Belawati H Widjaya: Fakultas Ilmu Komputer, Universitas Indonesia, Depok, Indonesia.

E-mail: bela@cs.ui.ac.id 